\title{
Krzysztof Gurba
}

Pedagogical University of Krakow

https://orcid.org/0000-0003-0144-7886

\section{Individual and Collaborative Online Learning - Reasonable Compromise}

\begin{abstract}
The collaborative attitude to education in general and e-learning in particular has become increasingly popular and productive. It preserves certain learning values connected with social context of learning and new phenomena of networking and using the tools of social media in education. Collaborative learning values include mutual inspiration, crowdsourcing, problem learning, peer learning and the like. More careful and elaborated look is necessary to pinpoint all important constituents of the overall positive account of social learning. One should take into account historical background and theoretical basis for a new wave in collaborative pedagogy.

At the same time, we face one of the greatest challenges in modern online learning, especially in its massive edition, including a new wave of MOOCs. It is a challenge of respecting an individual and open choice of learning path, even within more and more uniform massive online courses. One possible way of providing free choice of student's learning path is to offer more adaptive academic curricula.

The purpose of the study was to determine the students' attitudes toward community and individual online learning to explore their preferences in this regard, and to have them evaluate which of these forms held more promise for the future. In the study, we were also interested in tendencies in the choice of online learning and traditional learning, as well as factors that may influence the direction of these trends. The results showed that there are dichotomies and
\end{abstract}


conflicts between individual and collaborative online learning as far as sets of values are concerned. But the user practice shows that the reconciliation between the two is possible.

K e y w ord s: online education; individual online learning path; collaborative learning; learning values; human factor

\section{Introduction}

A properly understood openness in the choice of learning modules, enrolment solutions, pace of learning, self-control, moderate supervision and even new ways of self-assessing are not obstacles but challenges. But open access to educational resources and mechanisms of individual modelling of curriculum is not the only dimension of individualism in online education we want to study in this paper. One should take into account the organisational consequences of distributed and less regulated population of learners, the need to respect learning outcomes independently from their origin, need to integrate academic and professional skills and, moreover, necessary supporting mechanisms which provide constant consultation and aid for the learners.

On the other hand, the collaborative attitude to education in general and elearning in particular has become increasingly popular and productive. It preserves certain learning values connected with social context of learning and new phenomena of networking and using the tools of social media in education. Collaborative learning values include mutual inspiration, crowdsourcing, problem learning, peer learning and the like.

Our main goal in this paper is to summarize collaborative and individual learning values present in open education, and to analyse their impact on the learning effectiveness. Not every kind of positive factors in learning treated as a social phenomenon has the same influence and results in the same learning outcome. That is why the analysis will be useful in formulating the general, overall characteristics of the advantages of collaborative learning. On the other hand, we will study the value of learners having a free choice of individual path of learning. Positives of individual freedom to choose in this context are not only ideological or based only on the respect for human freedom of choice in general. There are obvious benefits one can derive from formulating and adapting an individual way, method, pace and kind of learning. A set of values attached to the social educational context is different from those present in the attitude to education respecting individual dif- 
ferences. From our analysis we will see how far they are from each other and to what an extend they contradict each other.

\section{Common history}

Collaborative learning is largely based on crowdsourcing, the use of collective wisdom, the power of a group of learners working together. Crowdsourcing is a term in its most recent meaning used since 2006, covering the use of distributed sources to solve micro and macro problems (Howe, 2008). An interesting and practical example of such a customisable service is Craigslist, a network of local classifieds and help sites, created in 1995, and then served as a benchmark for many social media services.

Many theorists note that crowdsourcing is a secondary term to the term "smart mob", proposed by Howard Rheingold in 2002, meaning a rational effect, a collective intelligence, emerging as a result of increased interaction (Rheingold, 2002). So looking at learning as a bottom-up collective activity is rooted in quite a long tradition.

The same is true for the history of the idea of personal learning. The idea of a personal learning environment (PLE) is even older. The term was used as early as in 1976 by Goldstein and Miller (Goldstein \& Miller, 1976). They were writing about the application of artificial intelligence methods to automated learning. The general idea behind the term is the creation of a personal learning environment by each individual learner, and thus the shaping of the learning activity by the learner $\mathrm{him} /$ herself. There is no ready-made scenario, no pre-imposed plan, no division between systematic education and informal or even non-formal education. Personalised learning tools and techniques are used. In modern terms, personal learning environment should be understood as independent, individualised, personalised learning. This individualised approach to distance learning also has quite a long tradition in the history of theoretical considerations of learning styles and various pedagogical attitudes. Hase and Kenyon wrote about this phenomenon as defining a separate type of pedagogy in 2000, using the term 'heutagogy'. With this approach to learning, it is described as a fully 'self-governed' process (Hase \& Kenyon, 2000). Since 2005, this individualised approach to online learning has been supported by a number of e-learning projects, including those related to the development of peer-to-peer training, supported by the use of wide-ranging open access educational resources (Gurba, 2014). 
A good institutional example of the application of collaborative teaching in the school education comes from Finland. Here the educational system underwent a real revolution. Finnish school classes no longer contain traditional subjects. Instead of particular subjects, like mathematics, physics, chemistry, history, geography, students will study events and phenomena in an interdisciplinary format. The Second World War will be studied from the multi-perspective of history, geography, and maths. Another course called 'Working in a Café' will allow students to absorb a whole multi-disciplinary knowledge about the English language, economics, and communication skills. A Finnish educational researcher and theoretician, Marjo Kyllonen, responsible within the Finnish educational authorities for the implementation of new methods of personalised learning, explicitly writes about the need for a 'new narrative' in describing the learning process (Kyllonen 2019).

The new teacher preparation system has ensured the successful implementation of a new style of teaching in schools. Teachers learn techniques for building student group motivation, become familiar with a range of techniques developed within educational psychology (Pressley 2020). 'The new trend sees teachers as developers in the whole school community. Teachers have research-based orientation in pre-service teacher education, which makes them capable to design school-based projects and their own development as it relates to school development' (Niemi 2015).

This system was introduced for senior students, beginning at the age of 16 . The general idea is that the students ought to choose for themselves which topic or phenomenon they want to study, bearing in mind their plans for the future and their individual capabilities. Choosing an individual learning path, the student will not have to pass through an entire course on mathematics or chemistry, but will obtain sufficient knowledge and skills necessary in the future professional life. Of course, it changes also the traditional format of teacher-pupil communication. A traditional class teaching no longer exists. Students work together in small groups to discuss and solve problems.

The liberation, opening of educational resources is intended to serve the greater availability of educational content that can be used by participants in the learning process, who, in the new type of learning environment therby created, can exchange information with a wide range of co-participants, complement each other, share knowledge and common educational resources. There are many ways in which groups can organise themselves into such non-individual, collective learning often referred to as a 'virtual community' of learners.

There are many undoubted advantages of such a collective community learning. But there are also many missing educational values in the collaborative attitude. In an individual learning the student has a sense of freedom from the framework of compulsion, from the planned learning path, from limitations in 
the pace and scope of learning. At the same time, however, an individual learning deprives students of valuable interaction with other learners, prevents project-based learning or inquiry-based learning. While in an individual learning, when choosing one's own learning path, the student has the possibility to adapt his/her learning style to his/her individual needs, to adjust the pace of acquiring knowledge, in the community learning, and social learning one uses various methods of interaction, cooperation in projects, controlling one's own mistakes, and taking advantage of the whole blessing of collective work.

\section{Need for balance}

The research generally shows the need for a reasonable balance between student freedom in the online learning process and supervision, control, and moderation by teachers. These two approaches can be sensibly combined, as Monika Weingartz, for example, has shown, indicating that student autonomy and independence in the learning process is best optimised by individualised selection of learning content, but also of the methods of control and academic supervision, best tailored by the student him/herself (Weingartz, 1990).

Another attempt to reconcile individual and collective approaches include courses called MOOLOs, which are a hybrid variant of MOOCs in which a set of learning modules, so-called learning objects, is made available to the student (Naidu, 2013). These are chosen by the student him/herself. In a similar way, Scharmer describes MOOC 4.0 courses as based on the use of both 'peer-to-peer' interaction and independent activities within formed subgroups or communities called 'social fields' (Schramer, 2014). In this way such local groups can make better use of the collective wisdom, while maintaining the relative autonomy of the participants in the learning process. Another name for a longer term initiative developed on a fairly massive scale is so-called Computer Supported Collaborative Learning (CSCL). Behind this name lies an approach in which the creative process in general and the learning process in particular is treated as a community endeavor. The CSCL community has for many years been developing its own tools, including online, social media tools to support this strand of collaborative learning. From a methodological point of view, this approach is called socio-constructivism.

The techniques for working and collaborating on course content fall within the broad field of participatory pedagogy. Within this model, different levels of participation are distinguished and the learning process, including the process of individual selection of the learning path, is adapted to the user's preference, which has been previously examined and precisely defined. Online educational content focused on passive participation is prepared differently from that focused on ac- 
tive participation. Despite the great variety of educational content and methods for an individual and collective learning, it is possible to maintain the value of self-regulation of the range, level and type of educational content, while taking advantage of the interaction in a larger group or broader community of learners. Such a proposal for balancing the two extremes was proposed by me, among others, in the form of a proposal for sMOOCs included in my 2015 book 'MOOCs - history and future' (Gurba, 2015). Of course, this was not a new discovery, but merely the formulation of a number of postulates in relation to MOOC-type courses. The idea of such a combination of peer learning with the choice of an individual learning path was already discussed in 2012 by Howard Rheingold, who referred to this type of pedagogy as 'peeragogy' (Rheingold, 2012).

\section{Methodology of research}

In a study conducted at the end of 2020 and within first weeks of 2021, we tried to find out to what an extent the experience of distance learning during the COVID 19 pandemic influenced the appreciation of the advantages of an individual educational pathway compared to learning in the collective, whether in a traditional or online mode. We conducted the survey on the sample of 91 persons, students of the Pedagogical University of Krakow. Our study group consisted in the students of social service; 81 female, and 10 male, aged between 19 and 23. The group of students to whom the survey was addressed consisted of 200 people. The target number of fully completed questionnaires is a purposive selection, so it has exploratory value. The questionnaire consisted of 16 questions, mostly with a single or multiple choice. The questionnaire was distributed using student email accounts and completed within the MS Forms application. The Spearman's coefficient was used to analyze correlations between variables, appropriate due to the presence of ordinal scale variables in the study.

Before the study we formulated the following hypotheses: The use of methods of an individual educational path selection in e-learning will be indicated as more effective than the use of collaborative learning methods (Hypothesis 1). There will be a significant association of the distribution of responses to question of an intensive use of e-learning in a group of respondents looking for individual learning environments and learning paths, and in a group respondents who prefer searching the collaborative learning environments (Hypothesis 2). We also hypothesized a high awareness of e-learning typologies and a higher level of appreciation of e-learning as an educational opportunity, and assumed that there will be a significant relationship in the distribution of answers obtained for questions about 
the promising prospects of e-learning and for question about a preferred form of e-learning environment. (Hypothesis 3).

\section{Results of research}

The students were surveyed about their online learning activities and their level of familiarity with online learning tools. As expected, the vast majority of respondents are online constantly. In this respect, they do not differ from the standard of their generation. Also, the declared rate of their social media activity in the time spent online is not surprising. The respondents indicated a level between 75 and $95 \%$ of the overall time spent in the Internet. When asked about a more advanced knowledge of online education tools, the students mostly declared a sufficient level of skills, allowing them to use search engines, instant messaging, e-learning platforms and open educational resources. However, this knowledge proved to be highly selective. The respondents are almost one hundred percent familiar with current tools in university teaching, such as MS Teams (100\% of respondents are familiar with this tool) or Moodle ( $98 \%$ of students are familiar with this e-learning platform). The concept of MOOC-type courses is known to $68 \%$ of those surveyed, but the names of popular MOOC platforms are less familiar: FutureLearn 55\%, Coursera 53\%, and Udemy $45 \%$. Students are not very familiar with the terms defining e-learning methodologies. For example, knowledge of the term "blended learning" is declared by only $22 \%$ of the survey participants, and $16 \%$ of students know the term "peer-learning". Slightly more, $17 \%$ of the respondents can define the term "collaborative distance learning".

The subjects were asked then the following complementary questions, concerning their attitude to e-learning as a future educational chance: Do you think that a collaborative e-learning at university is an educational opportunity? Do you think that an individual voluntary e-learning online is an educational opportunity?

The study found no significant differences between the responses to the two questions. The Spearman's rank correlation coefficient $r_{s}=0.81(p<0.01)$. The numbers of positive responses in both surveys are almost identical ( $38 \%$ and $40 \%)$. Comparing the two results in Figures 1 and 2, there is slightly more indecision about future prospects for online learning in the collaborative mode $(25 \%)$ than in the individual mode (18\%). Related to this, there is also less skepticism towards a collaborative learning as an educational opportunity (35\% of 'no' and 'rather not' responses) compared to the level of negative evaluation of such opportunities for an individual learning ( $44 \%$ of 'no' and 'rather not' responses). 


\section{Educational chance - collaborative}

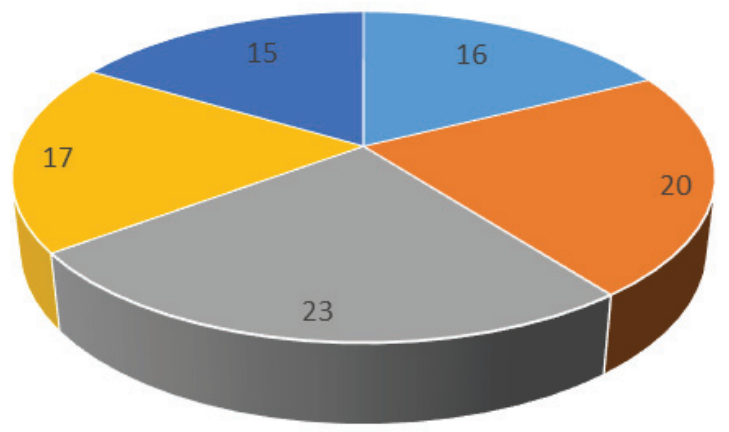

- Yes " Ratheryes " Hard to say " Ratherno " No

Figure 1. Collaborative e-learning as an educational chance.

\section{Educational chance - individual}

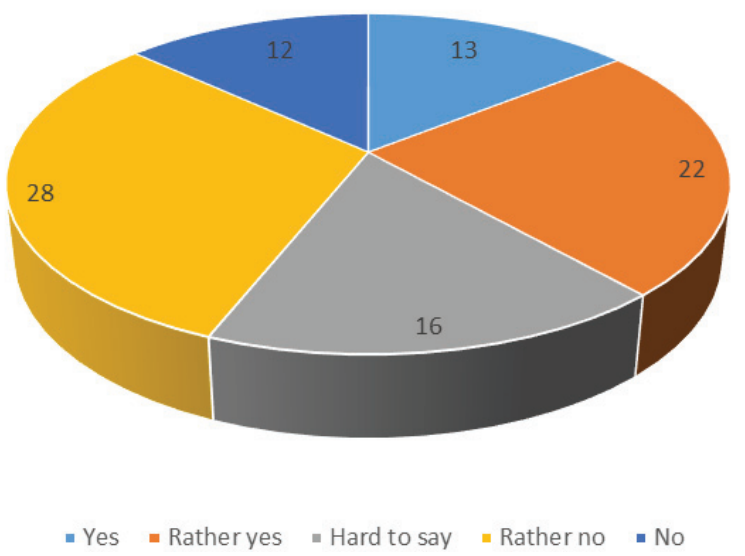

Figure 2. Individual e-learning as an educational chance.

The students were also asked about their own activity in terms of using e-learning outside classes and compulsory tasks. Such an activity was declared by two thirds of the respondents during the months preceding the survey, but the scope and intensity of this activity varied. Only $3 \%$ of the respondents studied additionally every day. $19 \%$ of the students undertook it every week and the rest (44\%) did it occasionally (Figure 3). 


\section{E-learning - additionally}

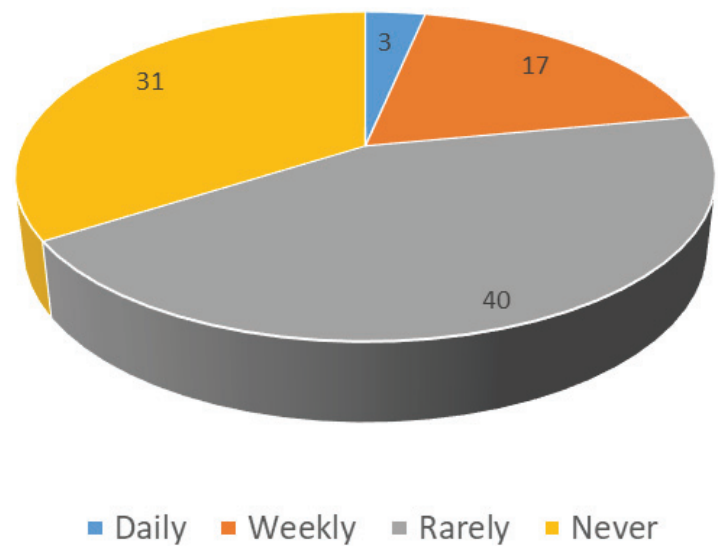

Figure 3. E-learning beyond the classes.

There is a (weak) positive correlation between the variable determining the additional educational activity in the network and indicators determining the respondents' attitude towards collaborative and individual learning, slightly higher for the group of supporters of individualised learning $\left(r_{s}=0.40, p<0.01\right)$ than for students indicating rather collective learning $\left(\mathrm{r}_{\mathrm{s}}=0.36, \mathrm{p}<0.01\right)$.

The respondents also declared their intentions concerning the future use of e-learning, for example after completing formal education (Figure 4)

\section{E-learning - future plans}

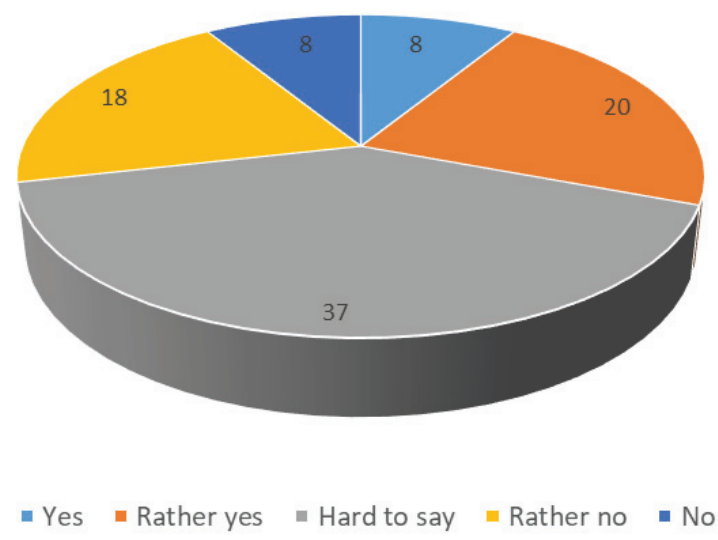

Figure 4. Declared future use of e-learning. 
Among those responding to this question, the number of positive responses is almost identical to the number of negative ones ( $31 \%$ and $29 \%$ respectively). Interestingly, the correlation of positive responses with positive attitudes towards online learning (collaborative and personalised) is significant $\left(r_{s}=0.41\right.$ and 0.50 respectively, $\mathrm{p}<0.01$ ) and again slightly higher in the case of those who prefer personalised learning.

The final issue of interest in our study was no longer a general evaluation of the future of online education and an assessment of its value as an educational opportunity, but the practical resolution of a specific, albeit hypothetical, situation of choosing a type of course. We asked the students whether, if one of the courses during their studies were available both in the traditional lecture version and in the fully online version, and gave the same number of ECTS credits, which of them they would choose. The results are illustrated in Figure 5. As can be seen, in a choice situation, students prefer lectures delivered in the traditional mode, faceto-face, in a class. This is the choice of about a half of the surveyed group (47\%). The lecture in the online mode would be chosen by $27 \%$ of the respondents. Interestingly, the preference for the online mode is very weakly positively correlated with the answers to the questions about the educational value of e-learning, but again the correlation is significantly higher in the case of those who highly value individualised learning $\left(r_{s}=0.34, p<0.01\right.$, against a value of $r_{s}=0.19, p=0.07$ for the preference for collaborative learning).

\section{E-learning - future plans}

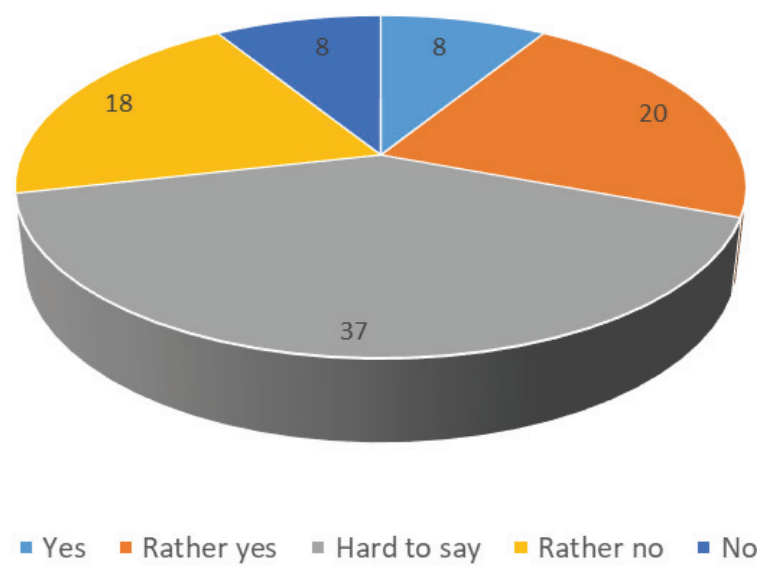

Figure 5. Traditional vs. online lectures - student's choice. 
A possible interpretation of these results would indicate the students' continuing attachment to traditional forms of learning, even despite their intense experience with online learning during the months of the Covid-19 pandemic. At the same time, those who favor individual forms of online learning and examination are more likely to choose the online mode of learning and examination, and they will be the ones more eager to appreciate the educational potential of the distance learning model.

\section{Discussion}

The results of the study partly confirm our Hypothesis 1 . Indeed, choosing individual learning paths is a more valued option among the students than collaborative learning. However, this preference is not significant. Nevertheless, the study did confirm our other hypothesis that the greater the experience of using e-learning tools, and the greater the belief in the significant educational value of online learning, the greater the preference for free and individual choice of learning paths will be.

A more intensive use of e-learning proved to result in bigger engagement in looking for individual learning environments and learning paths. Thus, the Hypothesis 2 was confirmed. But, looking at the results we cannot say that an individual choice of learning path is in contradiction with a collaborative attitude.

We can assume that the habits of group work in a traditional learning are strong enough to be transferred to habits in an online learning. Of course, we have to take into account the factor affecting students' attitudes during the Covid-19 pandemic. This factor was not distinguished in the present study due to the lack of comparative analysis available so far. Such a study will be performed after the cessation of restrictions. After all, there is no doubt that an intensive and circumstance-enforced use of e-learning tools results in a sense of missed or reduced interaction, which intensifies the demand for a return to collaborative learning.

Despite this increased intensity of students' immersion in e-learning, the awareness of typologies, methodological distinctions and the whole theoretical environment of online education did not prove to be high. Thus, the first part of our hypothesis 3 did not gain confirmation. On the other hand, the second part of Hypothesis 3 was confirmed, as indeed the subjects significantly appreciated the educational potential of e-learning. The part of the study that addressed this issue did not differentiate between individualistic and communitarian approaches. 
The contemporary development of school and academic e-learning consists of two seemingly competing trends: an individualistic and collaborative. They appear under different names and in different contexts, technological environments and educational methodologies. The researchers place these two trends in the perspective of Education 2.0 and the new Web 2.0 and Web 3.0 tools. For example, the studies analyze the usefulness of particular LMSs (Learning Management Systems) and their functionalities for students to create and implement their own Personal Learning Environments (Bartolomé \& Cebrian-de-la-Serna 2017). From this research, we conclude that students prefer software that, due to its flexibility and ease of use, allows them not only to select their own learning paths, but also to integrate it with their own external sources of educational content. The students extend the learning environments created even to their engagement in non-formal and informal learning. These results are consistent with those obtained in our study, which also indicated a link between the evaluation of personalized learning as an educational opportunity and current and projected future intentions to use an extra-curriculum online educational content.

Followingly, the concept of heutagogy (Hase and Kenyoa), cited by us as symptomatic of the development of personalized learning, developed one decade ago (McLoughlin \& Lee, 2010), has now returned as a theoretical framework to describe one of the dominant trends in modern online learning (Wismaningrum \& Prayitno \& Supriyanto, 2020).

There are few comparative studies conducted between social and personalized approaches; however, extensive analyses of the pros and cons of personalized learning environments include the attempts to reconcile both contemporary dominant trends. Susan Tenton, for example, weaves the research-based advantages of collaborative learning, such as the formation of communication competences, the acquisition of collaborative skills, and the feeling of integration into a group, into her analyses of the positive aspects of personalized online learning, such as the satisfaction and sense of independence, self-discipline, and self-actualization, as the co-creation of a vision of the student's presence and activity in the labor market, as the control over time (personalized learning implies a self-paced mode) (Tenton 2020).

\section{Conclusions}

The hypothesis with which we started this article, pronouncing the complementarity of the two types of online learning, has found significant confirmation. 
There is a reasonable compromise between an individualistic and collaborative online learning. However, ways and methods of reconciling the individual mode of selecting educational pathways with the advantages of community learning require further research, both in the context of recent experience with an accelerated and necessity-driven pandemic situation and, indeed, especially regardless of temporary circumstances.

A compromise and balance between individualism and collaborativism seems universally appropriate. It is worth developing existing theoretical schemes in which such a balanced approach to online education fits well (such as heutagogy). It is also worth revisiting theoretical distinctions that worked well in other contexts in the past. Such distinctions include, for example, the division of individualism and collectivism into vertical and horizontal, proposed as early as in 1995 (Singelis \& Triandis \& Bhawuk \& Gelfand, 1995). In the vertical understanding of collectivism, a group cooperation occurs despite the acceptance of differences among group members, and in the horizontal approach to collectivism, the focus is on blurring group differences. In contrast, vertical individualism emphasizes the autonomy and uniqueness of each individual, while the horizontal understanding of individualism emphasizes the equality and the need to strive for levelling of opportunity. Applying this important distinction to the study of the effectiveness of online education would be an interesting experience and is planned for the further course of our research. Further analyses of the forms and techniques of online learning by students will be confronted with a more detailed conceptual framework, to be incorporated into a refined research tool, resulting in the distinction of a greater number of possible predictors of distance learning effectiveness. At the same time, it will be possible to compare the results over an interval of time (longitudinal studies), which will, in the context of ongoing epidemic waves, provide additional insights into the phenomenon of the increasing scale of online learning, allowing conclusions on the dynamic context in students' attitudes towards an individual and collaborative e-learning.

\section{References}

Admiraal, W., \& Huisman, B., \& Van de Ven M. (2014). Self- and peer assessment in massive open online courses, International journal of Higher Education, 3 (3), 119-128.

Attwell, G. (2007). Personal Learning Environments: the Future of E-learning?, eLearning Papers, 2 (1), Retrieved from http://digtechitalia.pbworks.com/w/file/fetch/ 88358195/Atwell\%202007. pdf (accessed 27.03.2015). 
Baldazzi A., \& Ricci L., \& Valle Baroz V. (Eds.). (2011). E-learning Quality Assurance: A MultiPerspective Approach, Rome.

Bartolomé, A. \& Cebrian-de-la-Serna, M. (2017). Personal Learning Environments: A study among Higher Education students' designs. International Journal of Education and Development using Information and Communication Technology 13(2), 21-41.

Dillenbourg P. (Ed.). (1999). Collaborative Learning: Cognitive and Computational Approaches, Pergamon-Elsevier Science, Amsterdam.

Gillani, N., \& Eynon, R. (2014). Communication patterns in massively open online courses, The Internet and Higher Education, 23, 18-26.

Goldstein, I.P., \& Miller, M.L. (1976). AI Based Personal Learning Environment, AI Memo, Cambridge, $1-35$.

Glushkova, T., \& Gurba, K., \& Hug, T., \& Morze, N., \& Noskova, T., \& Smyrnova-Trybulska, E. (2021). New Technologies in Personalisation of STEM and STEAM Education - International Context, International Journal of Continuing Engineering Education and Life-Long Learning, Open Access, Inderscience Publishers.

Gurba, K. (2015). MOOCs - History and Future, Wydawnictwo Naukowe UPJPII, Krakow.

Gurba, K. (2014). Peer Learning and Beyond. In E. Arvanitis, \& A. Kameas (Eds.), Inercultural Mediation in Europe. Narratives of Professional Transformation (pp. 85-90). Common Ground, Champaign (IL).

Hase, S., \& Kenyon, C. (2000). From Andragogy to Heutagogy. Retrieved from http://ultibase. rmit. edu.au/Articles/dec00/hase2.htm (accessed 08.09.2021).

Holyfield, S. (2002). E-Learning Doesn't Have To Be Lonely - Learning Online Through Colloquia, Learning Technology 4 (1), 47-48.

Howe, J. (2006). The Rise of Crowdsourcing, Wired, 1-5.

Jain, A. (2013). Problem-Based Learning In MOOCs: Collaborating Online To Develop Realworld Skills, MOOC News and Reviews. Retrieved from http://moocnewsandreviews. com/ problem-based-learning-in-moocs-collaborating-online-to-develop-real-world-skills/ (accessed 08.06.2015).

Kyllönen, M. (2019). A New Narrative for the Future: Learning, Social Cohesion and Redefining "Us". In: J. W. Cook (ed.), Sustainability, Human Well-Being, and the Future of Education (pp. 311-338), Helsinki.

Martin, F.G. (2012). Will massive open online courses change how we teach? Communications of the ACM, 55 (8), 26-28.

McLoughlin, M.J.W. \& Lee, C. (2010). Personalised and self -regulated learning in the Web 2.0 era: International exemplars of innovative pedagogy using social software, Australasian Journal of Educational Technology 26(1), 28-43.

Naidu, S. (2013). Transforming MOOCs and MOORFAPs into MOOLOs. Distance Education, 34 (3), 253-255.

Niemi, H. (2015). Teacher Professional Development in Finland: Towards a More Holistic Approach. Psychology, Society, \& Education 7(3), 279-294.

Phan, T., \& McNeil, S.G., \& Robin, B.R. (2016). Students' patterns of engagement and course performance in a massive open online course. Computers and Education, 95, 36-44.

Pressley, T. (2020). Teaching Educational Psychology in an International Setting: Exploring the Finnish Education System. International Education Studies 13(7), 20-30.

Rheingold, H. (2012). Towards Peeragogy, DML Central, blog of Howard Rheingold, 2012. Retrieved from http://dmlcentral.net/blog/howard-rheingold/toward-peeragogy (accessed 24.09.2021).

IJREL.2021.7.2.08 p. 14/17 
Individual and Collaborative Online Learning - Reasonable Compromise

Schramer, O. (2015). MOOC 4.0: The Next Revolution in Learning and Leadership, Huff Post Education, 05.04.2015. Retrieved from http://www.huffingtonpost.com/otto-scharmer/ mooc40-the-next-revoluti_b_7209606.html (accessed 09.09.2021).

Singelis, T.M. \& Triandis, H.C. \& Bhawuk, D.P.S. \& Gelfand, M.J. (1995). Horizontal and Vertical Dimensions of Individualism and Collectivism: A Theoretical and Measurement Refinement. Cross-Cultural Research 29(3), 240-275.

Strijbos, J.-W. \& Kirschner, P. \& Martens, R. (Eds.). (2003). What We Know About CSCL In Higher Education, Kluwer, Amsterdam.

Tenton, S.R. (2020). Advantages and Disadvantages of Personalized Learning. In: S.R. Tenton, Evaluation of Principles and Best Practices in Personalized Learning, IGI Global Publisher, pp. 176-198.

Tomprou, M., \& Kim, Y.J., \& Chikersal, P., \& Woolley, A.W., \& Dabbish, L.A. (2021) Speaking out of turn: How video conferencing reduces vocal synchrony and collective intelligence. PLoS ONE 16(3): e0247655. Retrieved from https://doi.org/10.1371/journal.pone.0247655 (accessed 12.09.2021).

Weingartz, M. (1990). Selbstaendigkeit im Fernstudium, FernUniversitaet, Hagen.

Wheeler, S. (2015). Social, Mobile and Personal Learning Future, Wheeler Blog 25 March 2015. Retreived from http://steve-wheeler.blogspot.com/2015/03/social-mobile-and-personallearning. html (accessed 30.09.2021).

Wismaningrum, Y.R \& Prayitno, H.J. \& Supriyanto, E. (2020). Heutagogy Approach: The Implementation of New Normal Era Learning. Advances in Social Science, Education and Humanities Research 479, 189-193.

Yang, Q. (2014). Students' motivation in asynchronous online discussion with MOOC mode, American Journal of Educational Research, 2 (5), 325-330.

Zutshi, S., \& O'Hare, S., \& Rodafinos, A. (2013). Experiences in MOOCs: The perspective of students, American Journal of Distance Education, 27 (4), 218-227.

Krzysztof Gurba

\section{Indywidualne i zespołowe uczenie się online - rozsądny kompromis}

\section{Streszczenie}

Podejście oparte na współpracy w edukacji w ogóle, a w e-learningu w szczególności, staje się coraz bardziej popularne i skuteczne. Zachowuje ono pewne zalety uczenia się związane ze społecznym kontekstem edukacji i nowymi zjawiskami w sieci i oraz z wykorzystaniem narzędzi mediów społecznościowych w edukacji. Wartości uczenia się opartego na współpracy obejmują wzajemną inspirację, crowdsourcing, uczenie się problemowe, uczenie się przez rówieśników i tym podobne. Konieczne jest bardziej uważne i szczegółowe spojrzenie, aby wskazać wszystkie ważne elementy składające się na ogólny pozytywny obraz uczenia się społecznego. Należy wziąć pod uwagę tło historyczne i podstawy teoretyczne dla nowej fali w pedagogice współpracy.

Jednocześnie stoimy przed jednym z największych wyzwań współczesnej nauki online, zwłaszcza w jej masowym wydaniu, w tym nowej fali MOOCs. Jest to wyzwanie związane z poszanowaniem indywidualnego i otwartego wyboru ścieżki kształcenia, nawet w ramach coraz bardziej ujednoliconych masowych kursów online. Jednym z możliwych sposobów zapewnienia swobod- 
nego wyboru ścieżki edukacyjnej przez studenta jest oferowanie bardziej adaptacyjnych programów akademickich.

Celem badania było określenie postaw studentów wobec społeczności i indywidualnej nauki online, aby zbadać ich preferencje w tym zakresie, a także aby ocenić, która $\mathrm{z}$ tych form ma większe szanse na przyszłość. W badaniu interesowały nas również tendencje w wyborze nauki online i tradycyjnej oraz czynniki, które mogą wpływać na kierunek tych tendencji. Wyniki pokazały, że istnieją dychotomie, istnieją konflikty pomiędzy indywidualnym i zespołowym nauczaniem online, jeśli chodzi o zestawy wartości. Jednak praktyka użytkowników pokazuje, że możliwe jest pogodzenie tych dwóch wartości.

S łow a k lu c z o w e: edukacja online; indywidualna ścieżka kształcenia online; uczenie się kolaboratywne; wartości edukacyjne; czynnik ludzki

Кшиштоф Гурба

\title{
Индивидуальное и совместное онлайн-обучение - разумный компромисс
}

\author{
Анн о тация
}

Коллаборативное отношение к образованию в целом и электронному обучению в частности становится все более популярным и продуктивным. Оно сохраняет определенные ценности обучения, связанные с социальным контекстом обучения и новыми явлениями сетевого взаимодействия и использования инструментов социальных медиа в образовании. Ценности совместного обучения включают взаимное вдохновение, краудсорсинг, проблемное обучение, обучение с помощью сверстников и тому подобное. Для того чтобы определить все важные составляющие общего позитивного представления о социальном обучении, необходим более тщательный и детальный анализ. Необходимо учесть исторические предпосылки и теоретическую базу для новой волны в коллаборативной педагогике.

В то же время мы сталкиваемся с одним из самых больших вызовов в современном онлайн-обучении, особенно в его массовом издании, включая новую волну МООКов. Это проблема уважения индивидуального и открытого выбора пути обучения, даже в рамках все более и более унифицированных массовых онлайн-курсов. Одним из возможных способов обеспечения свободного выбора студентом пути обучения является предложение более адаптивных учебных программ.

Целью исследования было определить отношение студентов к общинному и индивидуальному онлайн-обучению, изучить их предпочтения в этом отношении и оценить, какая из этих форм более перспективна в будущем. В ходе исследования нас также интересовали тенденции в выборе онлайн-обучения и традиционного обучения, а также факторы, которые могут повлиять на направление этих тенденций. Результаты показали, что существуют дихотомии, есть конфликты между индивидуальным и совместным онлайн-обучением в том, что касается набора ценностей. Однако практика пользователей показывает, что между ними возможно примирение.

К л ю ч е в ы е с л о в а: человеческий фактор; человеческий фактор; индивидуальная траектория онлайн-обучения; совместное обучение; ценности обучения; онлайн-образование 
Individual and Collaborative Online Learning - Reasonable Compromise

Krzysztof Gurba

\title{
Aprendizaje individual y colaborativo en línea - Compromiso razonable
}

\author{
Resumen
}

La actitud colaborativa en la educación en general y en el e-learning en particular es cada vez más popular y productiva. Conserva ciertos valores de aprendizaje relacionados con el contexto social del aprendizaje y los nuevos fenómenos de creación de redes y uso de las herramientas de los medios sociales en la educación. Los valores del aprendizaje colaborativo incluyen la inspiración mutua, el crowdsourcing, el aprendizaje de problemas, el aprendizaje entre iguales y otros similares. Es necesario un examen más minucioso y elaborado para determinar todos los componentes importantes del relato positivo general del aprendizaje social. Hay que tener en cuenta los antecedentes históricos y la base teórica de la nueva ola de la pedagogía colaborativa.

Al mismo tiempo, nos enfrentamos a uno de los mayores retos del aprendizaje en línea moderno, especialmente en su edición masiva, incluyendo la nueva ola de MOOCs. Se trata del desafío de respetar la elección individual y abierta del camino de aprendizaje, incluso dentro de cursos masivos en línea cada vez más uniformes. Una posible forma de proporcionar la libre elección del camino de aprendizaje del estudiante es ofrecer planes de estudios académicos más adaptativos.

El propósito del estudio era determinar las actitudes de los estudiantes hacia el aprendizaje en línea comunitario e individual para explorar sus preferencias en este sentido, y hacer que evaluaran cuál de estas formas era más prometedora para el futuro. En el estudio también nos interesamos por las tendencias en la elección del aprendizaje en línea y del aprendizaje tradicional, así como por los factores que pueden influir en la dirección de estas tendencias. Los resultados mostraron que existen dicotomías, hay conflictos entre el aprendizaje en línea individual y el colaborativo en lo que respecta a los conjuntos de valores. Pero la práctica de los usuarios muestra que es posible la reconciliación entre ambos.

P a la bra s c lave: educación en línea; trayectoria individual de aprendizaje en línea; aprendizaje colaborativo; valores de aprendizaje; factor humano 